\title{
MULTICULTURAL COMMUNITY RATIONALITY IN RUNNING RELIGIOUS ACTIVITIES IN PANDEMIC TIMES
}

\author{
Riza Firly Maulidyah ${ }^{1}$, Agus Machfud Fauzi ${ }^{2}$ \\ ${ }^{1,2}$ Sociology S1 Study Program, Faculty of Social Sciences and Law, State University of \\ Surabaya, Indonenesia \\ riza.18091@mhs.unesa.ac.id, agusmfauzi@unesa.ac.id
}

Received: 13-07-2021 Revised: 27-09-2021 Accepted: 30-10-2021

\begin{abstract}
Indonesian society is a multicultural society that lives side by side with all the differences. In Indonesia, they are presently six official religions-namely Islam, Protestant Christian, Catholicism, Hinduism, Buddhism and Confucianism. It is this difference of belief that makes people live in peace and practice their respective religious teachings without any intention of disturbing the beliefs of others. The teaching of tolerance is also applied in one of the villages in Malang Regency, namely Peniwen Village. The majority of the population of this village are Protestant and Catholic Christians. Residents in this village always carry out religious activities in accordance with what has been ordered without any sense of demeaning other religions. The method used in this article is descriptive qualitative using Max Weber' s theory of rationality. The purpose of this article is to find out the rationality of the people of Peniwen Village in carrying out religious activities during the pandemic. This happened because during the pandemic almost all activities were limited. The results of this study demonstrate that the Village residents continue to perform religious activities by implementing health protocols and upholding tolerance between differing religious communities. The current health protocols regulate the number of congregants who will worship at the church, wearing masks, and maintain personal distance.
\end{abstract}

Keywords: Society, Multiculturalism, Religion, Pandemic Period

\section{Abstrak}

Masyarakat Indonesia merupakan masyarakat multikultural yang bidup berdampingan dengan segala perbedaan. Di Indonesia agama dibagi menjadi enam yakni agama islam, kristen, katholik, hindu, buddha, dan konghucu. Perbedaan keyakinan inilah yang menjadikan masyarakat hidup damai dan menjalankan ajaran agama masing-masing tanpa ada niatan untuk mengusik keyakinan orang lain. Ajaran toleransi juga diterapkan di salah satu desa yang ada di Kabupaten Malang, yaitu Desa Peniwven. Mayoritas penduduk dari desa ini beragama Kristen protestan dan Kristen katholik. Penduduk di desa ini selalu menjalankan kegiatan keagamaan sesuai dengan apa yang telah di perintabkan tanpa ada rasa untuk merendabkan agama lain. Metode yang digunakan dalam artikel ini adalah kualitatif deskriptif dengan menggunakan teori rasionalitas Max Weber. Tujuan dari adanya artikel ini adalah untuk mengetahui rasionalitas masyarakat Desa Peniwen dalam menjalankan kegiatan keagamaan dimasa pandemi, hal ini terjadi karena dimasa pandemi hampir semua kegiatan dibatasi. Hasil artikel ini adalah masyarakat Desa Peniwen tetap menjalankan kegiatan keagamaan dengan menerapkan protokol kesehatan dan tetap menjunjung tinggi toleransi 
antar umat beragama. Protokol kesehatan yang dilakukan adalah membatasi jumlah jemaat yang akan beribadah di gereja, memakai masker, dan menjaga jarak.

Kata Kunci :Masyarakat, Multikultural, Agama, Masa Pandemi

\section{INTRODUCTION}

Living with various differences has been a feature of Indonesian society since time immemorial. These differences start from customs, culture, ethnicity, language, beliefs, and religion. Because of these many differences, Indonesia is dubbed as a pluralistic country and a multicultural society ${ }^{1}$. Living side by side with all the differences does not automatically engender hostility or chauvinisme among the people of Indonesia. In fact, popular sentiment values these differences and advances a sense of tolerance. This is the case because all Indonesian people acknolwedge the political motto "Bhineka Tunggal Ika" ("unity in diversity) which has different meanings but remains one unit. The community is aware that only by uniting, respecting, increasing tolerance, and fostering brotherhood with others citizens will Indonesia improve and avoid internal discord ${ }^{2}$.

Everyone who lives in Indonesia is free to choose and adhere to beliefs of any religion or sect. As long as the individual is able to be responsible for what he believes in, does not harm or incite others, does not cause noise, and does not divide between individuals or groups in society ${ }^{3}$. The government guarantees the freedom to choose one's religion according to one's beliefs. This is also stated in the 1945 Constitution Article 28 E paragraphs 1 and 2. In addition, it is also regulated in Article 29 paragraph 1 of the 1945 Constitution. Freedom to choose and determine religion according to their respective beliefs is also an implementation of the Pancasila precepts ${ }^{4}$. First, namely, God Almighty. If it is regulated in Pancasila and the

\footnotetext{
${ }^{1}$ Khoirul Anwar, "Pancasila Village, Multicultural Education and Moderation of Diversity in Indonesia," Nazhruna: Jurnal Pendidikan Islam 4, no. 2 (June 13, 2021): 221-34, https://doi.org/10.31538/nzh.v4i2.1238; Achmad Asrori, "Contemporary Religious Education Model on the Challenge of Indonesian Multiculturalism," JOURNAL OF INDONESLAN ISLAM 10, no. 2 (December 1, 2016): 261-84, https://doi.org/10.15642/JIIS.2016.10.2.261-284; Mohd Roslan Mohd Nor and Maksum Malim, "Revisiting Islamic Education: The Case of Indonesia," Journal for Multicultural Education 8, no. 4 (November 4, 2014): 26176, https://doi.org/10.1108/JME-05-2014-0019.

2 Duna Izfanna and Nik Ahmad Hisyam, "A Comprehensive Approach in Developing Akhlaq: A Case Study on the Implementation of Character Education at Pondok Pesantren Darunnajah," Multicultural Education \& Technology Journal 6, no. 2 (June 8, 2012): 77-86, https://doi.org/10.1108/17504971211236254; Raihani, "Report on Multicultural Education in Pesantren," Compare: A Journal of Comparative and International Education 42, no. 4 (July 1, 2012): 585-605, https://doi.org/10.1080/03057925.2012.672255.

${ }^{3}$ Haris Supratno and Resdianto Raharjo, "Multicultural and Character Education as the Model of Mental Revolution Movement to Prevent Santri Radicalism" (Social Sciences, Humanities and Economics Conference (SoSHEC 2017), Atlantis Press, 2017), 156-59, https://doi.org/10.2991/soshec-17.2018.31; Abdul Wahid et al., "Learning Development Based On Multicultural In Inclusion School," Nadwa 12, no. 2 (January 7, 2019): 229_ 42, https://doi.org/10.21580/nw.2018.12.2.2744.

4 Abdul Chalik, "Religion and Local Politics: Exploring the Subcultures and the Political Participation of East Java Nu Elites in the Post-New Order Era," Journal of Indonesian Islam 4, no. 1 (June 1, 2010): 109-50,
} 
1945 Constitution then, people should be able to carry out all forms of worship in accordance with their respective religions. Every religion, of course, teaches all goodness and it is impossible to lead to negative things. Moreover, to hurt or provoke other religions. The proof of believing in the existence of God is by carrying out religious activities that have been ordered $^{5}$.

In Indonesia, six religions are recognized nationally, namely, Islam, Christian, Catholicism, Hinduism, Buddhism, and Confucianism. There are also various beliefs that are perfomed or undertaken by tribal folk in the rural areas of Indonesia, but these are not legally encoded because there are too many (and they lack theological coherence) ${ }^{6}$. As a country rich in multiple aspects ranging from culture, religion, wealth and natural beauty. There are several nicknames given, namely, maritime country, lungs of the world, emerald equator, country of a thousand islands, to the big muslim population. The last nickname is the nickname given by Muslims around the world to Indonesia. This happens because as many as 87 percent of the total population of Indonesia embraces Islam, based on global religious future data in 2010. Of this number, Islam in Indonesia is often referred to as the majority religion because its adherents are very large compared to the other five religions. In summary, religious identity ranging from worship, the existence of places of worship, celebrations of religious holidays and so forth - are all manifest in Indonesia

All religious communities strongly instill the values of tolerance so that differences in belief do not cause fear for adherents when undertaking their spiritual duties. Many are found in every area there is a religious identity that is felt to be unique. For example, there are house of prayer is one in a row in the elite residential area of Wiyung, Surabaya. This place of worship consists of a mosque, Protestant and Catholic Christian churches, pagodas, temples, and monasteries. A house of worship is one of the most important things to facilitate people

https://doi.org/10.15642/JIIS.2010.4.1.109-150; Amiruddin Siahaan, Tien Rafida, and Khairunnisa Batubara, "Influence of Madrasah Head Leadership, Motivation and Madrasah Culture on Teacher Performance in Madrasah Aliyah Model 2 Medan," Budapest International Research and Critics Institute (BIRCI-Journal): Humanities and Social Sciences 3 (August 3, 2020): 2174-82, https://doi.org/10.33258/birci.v3i3.1150.

${ }^{5}$ Leonora C. Angeles and Omer Aijazi, "Revisiting the Madrassa Question in Pakistan: Worlding Lived Religion and Religious Education in Urban Spaces," Humanity \& Society 43, no. 3 (August 1, 2019): 295-326, https://doi.org/10.1177/0160597618814878; Dirga Maulana, "The Exclusivism of Religion Teachers: Intolerance and Radicalism in Indonesian Public Schools," Studia Islamika 24, no. 2 (August 31, 2017): 395-401, https://doi.org/10.15408/sdi.v24i2.5707.

6 Mohammad Hamid Mohammad al-Aharish, "Indonesian Islam and Social Challenges Between Moral Cultivation and Intellectual Movement," Journal of Indonesian Islam 11, no. 2 (December 6, 2017): 551-568-568, https://doi.org/10.15642/JIIS.2017.11.2.551-568; Alexander R Arifianto, "Islamic Campus Preaching Organizations in Indonesia: Promoters of Moderation or Radicalism?," Asian Security 15, no. 3 (September 2, 2019): 323-42, https://doi.org/10.1080/14799855.2018.1461086. 
to worship ${ }^{7}$. In addition to Surabaya, the establishment of houses of worship from religions across Indonesia are also in Bali. The complex where the religious site is located is called Puja Mandala Nusa Dua, Bali. Inside this complex are the Great Mosque of Ibn Batitah, the Catholic Church of Mary Mother of All Nations, the Bali Protestant Christian Church (GKPB) for the Bukit Doa Congregation, the Guna Buddha Temple, and the Jagatnatha Temple.

Not only are places of worship built in rows in Indonesia, there are also villages or settlements where all of the citizens adhere to a particular religion. One such, is Peniwen Village in the Kromengan District, Malang Regency. Residents in this village are mostly Christians, however, they still live in harmony with residents who have different beliefs or with other villages. Religious adherents generally undertake their spiritual activities together, whether it is prayer, weekly church attendance, going to temples, pagodas, or celebrating religious holidays.

Since March 2020, the situation became radically different following the covid-19 outbreak. This has included educational activities, work, tourism, and all religious activities. Normal conditions and freedom to worship are now subject to strict rules, guided by stringent health protocols. The process of writing research requires a lot of references and literacy resources. This is useful to enrich the theory used in reviewing the research to be carried out. In this study, the author utilised several previous studies or research that had been undertaken and had the same theme. The first research entitled "Tolerance of People of Different Religions (Study of Social Interaction of Religious People in Krisik Blitar)" by Suvia Nisa' aimed at the form of tolerance practiced in Krisik when interacting with people of other religions. This study employed qualitative research methods and demonstrated that there are three categories or forms of tolerance between religious communities in Krisik. Firstly, accepting differences that have a consequential dimension to the form of religious tolerance. Furthermore, separating activities between social activities and beliefs that have a knowledge dimension with a form of social tolerance. Lastly, mixing understanding that has a knowledge dimension with a form of ritual tolerance ${ }^{8}$.

The second pertinent was entitled "The Harmony of Life of Different Religions and Streams: Interaction of Nabdliyin, Christians, Buddhists, and Ahmadis in Kudus" by Moh Rasyid and aimed to

7 Robi’atul Maulidah, "Toleransi Umat Muslim Terhadap Keberadaan Gereja Pantekosa Di Surabaya," Religio: Jurnal Studi Agama-Agama 4, no. 2 (2014): 195-217.

8 Suvia' Nisa, "Toleransi Masyarakat Beda Agama (Studi Tentang Interaksi Sosial Umat Beragama Di Krisik Blitar)," 2019. 
the harmony that is formed in the inter-religious life of the religious community in Kudus. This study uses a qualitative descriptive method with observation and interview techniques. The results obtained from this study are that there is a very close harmony between residents even though they have different beliefs. This occurs because of the social awareness of citizens regarding the cultural and economic aspects of the majority who so that they are not easily ignited by conflict, and rather cultivate feelings and ties of communal brotherhood ${ }^{9}$.

The third relevant study was entitled "Tolerance of Religious Interfaith Housing Area" by Ika Fatmawati Faridah, which aimed to determine the tolerance that was formed between religious communities in variant housing areas. Housing environments are noted for the individualistic and independent attitude of their inhabitants because such characters feel able to slove problems and are more prone to communal conflict. This article uses a descriptive qualitative research method. The results obtained suggest there is a high level of intercommuna tolerance in the Penembongan housing environment and that there has never been substantial conflict between religious communities here because they possess the view that religion and belief are personal matters and their civic duty is to these differences ${ }^{10}$. A fourth study entitled "From the Elegy Pulpit, Local Wisdom, and Cooperation: Behavior of Religious Harmony in Salatiga and Manado Communities" by Benny Ridwan examined the harmony and peace that was created and maintained in a heterogeneous society. This study uses a qualitative method. The results obtained infer that the maintenance of tolerance harmony and peace reflect the community priorities of brotherhood, mutual respect, and non-interference in the religious affairs of others ${ }^{11}$. The most recent previous research, entitled "Knowledge, Attitudes, and Actions of Religious People Facing Covid-19" by Akmal Salim Ruhana and Haris Burhani aimed to determine the knowledge, attitudes, and actions of religious people in dealing with the covid outbreak while at the same time knowing how obedient they are to theological prescriptions. The method used is to conduct an online survey through a licensed survey monkey application. The questionnaire links that have been created are distributed through whatsapp groups, facebook, and instagram. The results obtained are that the public is aware of the occurrence of this epidemic, how it is transmitted, and must follow health protocols when worshiping ${ }^{12}$. Of the

9 Moh. Rosyid, "KESELARASAN HIDUP BEDA AGAMA DAN ALIRAN: Interaksi Nahdliyin, Kristiani, Buddhis, Dan Ahmadi Di Kudus," Fikrah 2, no. 1 (2014): 75-94.

${ }^{10}$ Ika Fatmawati Faridah, "Toleransi Antarumat Beragama Masyarakat Perumahan," Jurnal Komunitas 5, no. 2 (2013): 267-79.

11 Benny Ridwan, "DARI MIMBAR RELIGI, KEARIFAN LOKAL, DAN KERJASAMA (Perilaku Kerukunan Beragama Masyarakat Salatiga Dan Manado)," 2018,1-23.

12 Akmal Salim Ruhana and Haris Burhani, "Pengetahuan, Sikap Dan Tindakan Umat Beragama Saat Menghadapi Covid-19," Laporan Survei, 2020, 1-49. 
five references to previous research, of course, there are differences with the research to be carried out.

The difference lies in the focus of study. Researcher are trying to see and want to know the rationality of the multicultural community of Peniwen village carrying out worship activities during the pandemic. Are there differences that create conflicts? or even greater communal tolerance? Another interesting thing is the current conditions, where the COVID19 pandemic does not end and requires people to be able to adapt in all activities including worship activities or religious activities.

\section{RESEARCH METHODS}

In this article, I employ a qualitative research model using the literature study method in data collection. Literature study is a technique to find references on theories that are relevant to the problem being investigated by researchers. This technique involves the collection of data based on books, journals, theses, and the results of previous studies that have the same theme and connection. In addition, the study of literature aims to prove or disprove relevant theories in accordance with the problems studied by researchers as material for future discussion and reference ${ }^{13}$.

This literature study method was chosen because of the circumstances that made it impossible to conduct research directly due to the covid-19 pandemic. To complement the accuracy of the data from the results of the literature review, the researcher will also conduct online interviews with one of the residents who live in Peniwen Village. Interviews were conducted using a digital platform, namely WhatsApp. The purpose of the interview is to add the necessary data related to the article.

In this study, the theoretical approach used is the theory of rationality proposed by Max Weber (1864-1920). This theory postulates that every taken by each individual has a reason and meaning, whether it is experience, understanding of an object, or the individual's assessment. Whether it's experience, understanding of an object, and the individual's assessment of a thing ${ }^{14}$. People certainly have their own reasons and there is a serious cognitive purpose and utility that underlines during the pandemic. Of course, the multicultural community living in Peniwen Village has a strong reason when undertaking and performing religious activities, and it is hoped that worship will serve to increase communal tolerance

\footnotetext{
13 Melfianora, "Penulisan Karya Tulis Ilmiah Dengan Studi Literatur," Open Science Framework, 2017, 1-3.

${ }^{14}$ M Chairul Basrun Umanailo, “Max Weber,” 2017, 1-5, https://doi.org/10.4324/9780203786093.
} 
among fellow religious believers (even though the village is well-known for being a Christian majority community).

This study uses three stages of data analysis techniques. The first is data reduction, which is the stage for analyzing, collecting, sharpening, classifying, and sorting the relevant materal that has been obtained and the result of interviews through telephone calls to informants, namely village resident. Second, data presentation is a technique used to compile or combine all existing information so that from the information a conclusion can be drawn. The form of presentation of this research is data that can be in the form of interview evidence whether it is via WhatsApp video calls, voice messages, or other virtual messages. This study uses a qualitative method so that the most common data presentation is by being parsed or described which is narrative and descriptive. The last data analysis technique is drawing conclusions. In this last technique to get and be able to draw a conclusion, the way to do it is to read the whole result and understand it. The whole process or technique of data analysis aims to solve a conundrum that occurs during the research process.

\section{RESULTS AND DISCUSSION}

\section{Multicultural Society}

Nations that are categorized as multicultural societies are those based on complex social differences ${ }^{15}$. The term multicultural is synonymous with multiple cultures, religions, ethnicities, races, groups, and customs. Having a very wide geographical area - stretching from Sabang to Merauke-means that Indonesia posses much societal diversity and countless cultures. These complicated differences may be prone to disputes or divisions between ethnic groups within the republic in Indonesia if the country is not shored up on a foundation. Disputes are liable to occur if each tribe or group is permitted to prides itself excessively over other social units. It is therefore considered important to constantly emphasize mutual respect and tolerance within the framework of the civil rights of the individual. This sentiment is reflected in the official motto of the Indonesian state, Bhineka Tunggal Ika, which means different but still one.

In Indonesia, a unique multicultural society is spread throughout the region. Each island or district posses its own peculiar characteristics. They have different habits and ways of interacting between people ${ }^{16}$. One of the most obvious and prominent aspects of the

15 Mahdayeni, Muhammad Roihan Alhaddad, and Ahmad Syukri Saleh, "Manusia Dan Kebudayaan (Manusia Dan Sejarah Kebudayaan, Manusia Dalam Keanekaragaman Budaya Dan Peradaban, Manusia Dan Sumber Penghidupan)," TABDIR: Jurnal Manajemen Pendidikan Islam 7, no. 2 (2019): 154-65, https://doi.org/10.30603/tjmpi.v7i2.1125.

16 Parsudi Suparlan, "Masyarakat Majemuk, Masyarakat Multikultural, Dan Minoritas: Memperjuangkan Hak-Hak Minoritas.," Pusat Dokumentasi ELS AM, n.d., 2-4. 
multicultural society in Indonesia is differences in beliefs. Indonesia recognizes six main religions, namely Islam, Protestant Christianity, Catholic Christianity, Hinduism, Buddhism and Confucianism. That does not include the beliefs held by the various tribes in each region. Indonesia is a country where the majority of the population is Muslim. The number of adherents of the Islamic religion in Indonesia reaches 229 million people or statistically of the total $87.2 \%$ number. People who follow Islam are scattered throughout the archipelago. They live side by side with other religions such as Christianity, Catholicism, Hinduism, Buddhism, and Confucianism. This religious difference do not make the Indonesian people a society that denigrates minority faiths or favor their own religion.

For these reasons, the Indonesian state may be described as rich in culture and its people are dubbed multicultural with all their differences ${ }^{17}$. Even though it grows predicated on various differences, multicultural society still lives side by side with all elements of different cultures. Even thought it grows, based on these various differences multicultural society thrives because basically what is needed when living side by side is a high sense of tolerance and mutual respect. For the life of a multicultural society, differences are not a barrier, but rather, a unifier among its citizens.

\section{Peniwen Village, Kec. Kromengan, Kab. Poor}

Malang Regency is the district with the second largest area in East Java. Its territory consists of 33 sub-districts, 12 sub-districts, and 378 villages. One of the villages in Kromengan District, Malang Regency, is unique for having prominent differences in beliefs from neighbouring villages. In fact, it is often referred to as a Christian village because the majority of the population in Peniwen Village is Christian. Statistically, the Christian population consistute $95 \%$ of the total number of inhabitants. In this village there is one church that has a long story in the region and has existed since the Dutch era, namely, GKJW (Jawi Wetan Christian Church) the Christian Congregation. This church has become an iconic part of the Peniwen village. Built in 1931, it combines colonial style with Javanese architecture. Consequently, the construction of this church at the time was adapted to the tropical climate of the Malang area so that, for instance, the structure possess a high main door with two large windows on the right and left of the door. The shape of the building is also very close to traditional Javanese culture, namely, the typical joglo style with various kinds of ornamentation

17 Middya Boty, "Masyarakat Multikultural: Studi Interaksi Sosial Masyarakat Islam Melayu Dengan Non Melayu Pada Masyarakat Sukabangun Kel. Sukajadi Kec. Sukarami Palembang," JS A 1, no. 2 (2017): 1-17. 
made of wood. So, when the Europeans introduced and propagated the teachings of the Christian religion, they did not necessarily overwhelm the native culture.

The approach taken was to combine the two cultural paradigms in order to convey the protestant faith along local understandings. In other words, they adjusted the architectural style to the conditions and culture of the native community so that the specific religious teachings could be easily understood. In this manner, they were able to attract the attention and participation of such people who embrace the teachings of the Christian religion. Based on the history of the village of Peniwen, peni is an abbreviation of the word nyimpen or deviated from something, whereas, wen is short for deduwen which means ownership of an item or another. Although, until recently, it is still widely known as a Christian village, the locale also reflects the existence of a multicultural society. This is marked by the entry of other religions such as Islam and Hinduism that coexist with the Peniwen village community.

It is also undeniable that the development of religions and cultures other than Christianity is also growing very rapidly throughout the archipelago, especially Islam which is the majority religion in Indonesia. The entry of other religions into the village of Peniwen can be seen from the establishment of an Islamic Orphanage named Dar Ar-Rabman Lil Aitam, and places of worship such as prayer rooms. These differences have not raised apprehensions among the people of Peniwen village but have been employed by local civic leaders to encourage mutual communal respect, promote tolerance, and foster brotherhood. Mosk folk in Peniwen Village wok as farmers in the fields. This is because of the geographical location of Peniwen village which is on the slopes of Mount Kawi. In addition to having people who are predominantly Christian, this village is also known for its beautiful natural beauty.

In recent years this natural beauty has been utilized and developed by the local community to attract tourists and increase communal revenue and divesify employment, increase income for residents, and improve welfare and the economy. The village tourism developed by the local community itself is open to public, which means it accepts both domestic and international tourists who want to learn more about Peniwen village and the surrounding region. There are tour packages provided by the local community so that tourists can choose and adjust their funds. The tour package consists of learning to plant in the fields, learning the culture and history of Peniwen village, introducing gamelan culture, showing the natural beauty of Peniwen village, and much more. Generally, Peniwen village will be crowded towards the end of the year to welcome the new year.

\section{Religious Activities}


It is known as a Christian village because almost 95 percent of its people embrace Christianity, making Peniwen village an area or place that is thick with religious activities. However, Peniwen village itself has experienced some social development with the entry of other religions such as Islam and Hinduism. The number of adherents of other religions who enter the village is not as much as the majority of adherents of the original. Christianity remains the majority religion. Because of this coexistence, religious activities are not only about those who are Christians but also those who carry out their own religious traditions. However, when entering the Peniwen village, other religions besides Christianity experienced rejection and conflict with the community. This can be handled properly so that it does not cause a prolonged conflict.

As time goes by, the community can accept and open their hands to those (not the original Peniwen villagers) who want to settle down and live life in the village even though they are not Christians. People are very aware that the Indonesian state is also built on all differences, whether it's differences in understanding, culture, customs, language, and much more. It would be unethical and impolite to blame the beliefs of each individual as a reason for triggering conflicts and disagreements. Religious affairs in Peniwen village are indeed dominated by those who are Christians, it can even be seen that the religious activities of Christians are very prominent. However, this does not make those who are not from the Christian religion feel isolated or inferior.

They continue to carry out their religious activities in accordance with the teachings and beliefs they profess. The important point of the religious activities of the majority and minority religion in this village being able to function side without any conflict has been an atmosphere of mutual respect and the active promotion of tolerance. The Peniwen village believe that only by respecting and always tolerant, what is produced is only peace without division, conflict, and conflict. The attitude shown by the village community to respect religious activities is to provide mutual support, not to make noise at other religious events, not to interfere, and to help each other if other religions need help during celebrations or religious activities require the energy of many people.

The people of Peniwen village always go to church every Sunday, celebrate Christmas, Easter, and many others in an orderly manner and do not try to influence followers of other religions. Likewise, those who are Muslim also worship according to the teachings that have been trusted and also do not have an influence on other religions. Other factors that make the community so harmonious and have a very high tolerance for followers of other religions are 
heredity factors, struggle values, leadership, and cooperative values when the village was formed.

The harmony that is formed in respecting the religious activities of other religions is because the people in this Peniwen village always help each other regardless of their faith background, the social interactions that are formed in each individual are also very deep, and the cooperation of the villagers themselves who always strive to create peace. So as not to question basic things such as differences in beliefs. Because people believe even though they have different beliefs, the teachings in each religion never teach something bad and always teach good. There has never been a theological teaching or activity that instructs its adherents to hate, ridicule, and demean other religions. Therefore, religious activities carried out by the multicultural community in Peniwen village are also able to have a good impact on the community itself. People can also learn many things not only from their religion but also from the culture of goodness of other religions.

\section{Worshiping during a Pandemic}

Currently, Indonesia is in a situation where all social activities must adhere to strict health regulations. These strictures start with mandatory mask wearing, social distancing in crowds, diligent personal hygiene in hard washing, and much more. This has happened because Indonesia has been hit by the covid-19 virus pandemic for over a year and this has caused hundreds of thousands of people to die. In Indonesia alone, to date, 1.41 million have been confirmed positive for covid-19, 1.23 million have recovered, and 38,229 have died. This is something that all Indonesian people must pay attention to ${ }^{18}$. If before the arrival of Covid, all activities undertaken by the community were running normally, then currently every activity is required to reduce crowds, follow health mandates such as wearing facemasks, provide a place to wash hands with running water and soap, and the maintenance of approximately one meter distance from other individuals.

This policy also applies to religious activities carried out by the community. This rule is applied starting from the implementation of worship every week in the church, the implementation of the worship in the month of Ramadhan, and all celebrations of religious holidays in Indonesia. When Christians want to worship in church, they must sit according to the distance that has been set, cannot be close together as usual and must always wear a mask. Restrictions on the number of congregants who wish to worship in person at the church are

18 Meliza, Deri Wanto, and Lukman Asha, "Persepsi Masyarakat Sukaraja, Rejang Lebong Terhadap Edaran Menteri Agama Nomor: SE. 6. Tahun 2020 Mengenai Tata Cara Beribadah Saat Pandemi," MANHAJ: Jurnal Peneltian Dan Pengabdian Masyarakat 9, no. 1 (2020): 1-17. 
also limited. This is done so that all congregations can worship every week, church administrators facilitate online worship that can be accessed by the congregation from their respective homes. Likewise, during Christmas celebrations, it should not be too crowded. This is what the people of Peniwen village do. Even though, in conditions that are always limited, it doesn't make their enthusiasm to perform worship in the midst of a pandemic fade and just disappear. They have learned new things about the technology that is currently developing. The public also realizes that the use of technology is not only intended for those who study IT but, for all individuals in this world. Worshiping during this pandemic brings its own challenges for the multicultural community living in Peniwen village. The challenge is getting used to always implementing health protocols even though it is considered uncomfortable. In addition, they are also able to increase tolerance and mutual respect for the implementation of other religious worship in the midst of a pandemic situation. The villagers work hand in hand to ensure that all residents can worship comfortably and feel safe. For this reason, the application of health protocols is not only carried out and applies to Christians, but to all religious people ${ }^{19}$.

Living side by side with all differences is not something that is easily carried out, moreover, these differences are related to the beliefs held ${ }^{20}$. However, the basis of the unity formed in Indonesia is to respect all these differences. Indonesia is known by countries in the world because of its differences. The differences that make Indonesia rich with diversity of tribes, languages, cultures, and customs ${ }^{21}$. Indonesia is a muslim majority country. However it is undebiable that there are areas in Indonesia where the majority of the adherents of the religion are not Islam, but Christians, Buddhists, and Confucians. On the island of Bali, for example, the main religion is Hinduism and the Muslims (and other) constitute a faith minority. The number of people who are Muslims or others can be counted and are religious minorities. This reality does not neccessitate inter-communal tension or violence. All groups strive to maintain mutual respect and tolerance, and do not interfere with the celebration of their respective religious holidyas.

${ }^{19}$ Raza A. Mir, "Religion as a Coping Mechanism for Global Labor: Lessons from the South Asian Shia Muslim Diaspora in the US," ed. Jawad Syed and Edwina Pio, Equality, Diversity and Inclusion: An International Journal 32, no. 3 (January 1, 2013): 325-37, https://doi.org/10.1108/EDI-12-2012-0111; W.H. Clark, The Psychology of Religion: An Introduction to Religious Experience and Behavior (New York: Literary Licensing, LLC, 2012), https://books.google.co.id/books?id=kyeIMQEACAAJ.

${ }^{20}$ Nabila Quway, "Intergrasi Multikultural Dalam Masyarakat Multietnis (Jawa, Cina, Dan Arab Keturunan) Di Kota Semarang," Jurnal IJTIMAIY AH 2, no. 1 (2018): 90-110.

${ }^{21}$ Ahmad Syarqawi, "Masyarakat Multikultural," n.d. 
At first, the appearance of other religions such as Islam and Hinduism in this village received a negative reaction. Because they assume that, the history of the formation of this village began with the spread of Christianity that occurred. The historical foundations of the village were rooted in the spread of Christianity amongst the native population, and villagers were apprehensive about immigration and integration of adherents of other religious traditions. Initially, the apprehension undermined village harmony and peace. So, ultimatley they realized it would be better to accept and live with all the differences. Religious activities that occur in this village are also running as they should without any abstacles. The community has been able to accept, help and respect each other, and always strive for tolerance.

Even during the covid-19 pandemic, they continue to carry out religious activities according to the teachings of their respective religions. However, there are differences and rules that apply when the implementation of religious activities takes place in pandemic conditions like this. Religious people are required to apply health protocols when worshiping in places of worship that are used by everyone ${ }^{22}$. Both the church and the prayer room that are there all apply health protocols to take care of themselves and others who worship. The community works hand in hand and always works together to take care of each other. The use of technology is also applied by the Church members of the Peniwen village, besides gradually waiting for their turn to worship every week, they also utilise the youtube channel to listen to the words of the Bible through live broadcasts. Diverting worship activities that are usually carried out in person to online, is an effort for residents to minimize the prevention of covid$19^{23}$.

For this reason, this is closely related to rationality and the reason the multicultural community continues to worship in pandemic conditions. The underlying reason is because religious activities are an obligation for every religious believer. Religious activities are also an existence of the people themselves so that others know that they have faith. Although religious activities in Peniwen Village are not as crowded and free as usual from conditions before the pandemic, the community carries out with seriousness and solemnity because worship is a direct communication aimed at God. The people of Peniwen village believe that, by continuing to carry out religious activities in accordance with the health protocols that have been implemented by the government, they will still feel safe and can worship in peace.

\footnotetext{
22 Abdul Syatar, Muhammad Majdy Amiruddin, and Arif Rahman, "Darurat Moderasi Beragama Di Tengah Pandemi Corona Virus Desease 2019 (Covid-19)," Jurnal Kurioritas: Media Komunikasi Sosial Dan Keagamaan 13, no. 1 (2020): 1-13, https://doi.org/10.35905/kur.v13i1.1376.

23 Andini Nurrahmah Dewi and Agus Machfud Fauzi, Peran Tokoh Agama Dalam Meningkatkan Religiusitas Warga Desa Giri, Kabupaten Gresik Di Masa Pandemi Covid-19, Tajdid, vol. 24, 2021.
} 


\section{CONCLUSION}

In Indonesia, religious activities carried out by religious people are also based on respect and increasing tolerance because matters of belief and faith are personal matters under no legal obligations. When the covid-19 pandemic entered Indonesia over a year ago, the order of people's lives changed, including the aspect of undertaking religious activities. Even now, religious activities performed in place of worship or during religious holidyas are somewhat different from normal conditions.

This also happened in Peniwen village, Kec. Kromengan, Kab. Malang, where the majority of the people follow Christianity. Religious activities in this village - both those of the majority religion and the minority faiths such as Islam and Hinduism - are functioning as normal, and still implementing health protocols according to government recommendations. This health protocol is followed, in addition to personal and public hygiene measures, in all places of worship that are used by many people. The multicultural community environment in the village of Peniwen appear to genuinely comprehend the neccessity of mutual respect and aid during times of crisis such as a health pandemic in order to maintain everything. There are many ways to make the process of carrying out religious activities run smoothly and safely. The people of Peniwen Village continue to update information about the current covid-19 condition in Indonesia. This is to ensure that the policies set by the government can be implemented properly.

It seems the residents of Peniwen Village appreciate their differences and try to foster harmony. They comprehend the principle that differences will always exist in life, especially in matters of faith, but thet is not an excuse to avoid a peaceful and tolerant life. For this reason, the people of Peniwen Village continue to carry out religious activities during the pandemic on the basis of the mutual tolerance between inhabitants.

\section{Acknowledgement}

The author is very grateful to the parties involved such as the supervisor, the Peniwen Village community, and all who have helped in completing the writing of this article.

\section{REFERENCES}

Aharish, Mohammad Hamid Mohammad al-. "Indonesian Islam and Social Challenges Between Moral Cultivation and Intellectual Movement." Journal of Indonesian Islam 11, 
no. 2 (December 2017 ): https://doi.org/10.15642/JIIS.2017.11.2.551-568.

Angeles, Leonora C., and Omer Aijazi. "Revisiting the Madrassa Question in Pakistan: Worlding Lived Religion and Religious Education in Urban Spaces.” Humanity \& Society 43, no. 3 (August 1, 2019): 295-326. https://doi.org/10.1177/0160597618814878.

Anwar, Khoirul. "Pancasila Village, Multicultural Education and Moderation of Diversity in Indonesia." Nazhruna: Jurnal Pendidikan Islam 4, no. 2 (June 13, 2021): 221-34. https://doi.org/10.31538/nzh.v4i2.1238.

Arifianto, Alexander R. "Islamic Campus Preaching Organizations in Indonesia: Promoters of Moderation or Radicalism?" Asian Security 15, no. 3 (September 2, 2019): 323-42. https://doi.org/10.1080/14799855.2018.1461086.

Asrori, Achmad. "Contemporary Religious Education Model on the Challenge of Indonesian Multiculturalism." JOURNAL OF INDONESIAN ISLAM 10, no. 2 (December 1, 2016): 261-84. https://doi.org/10.15642/JIIS.2016.10.2.261-284.

Boty, Middya. "Masyarakat Multikultural: Studi Interaksi Sosial Masyarakat Islam Melayu Dengan Non Melayu Pada Masyarakat Sukabangun Kel. Sukajadi Kec. Sukarami Palembang." JSA 1, no. 2 (2017): 1-17.

Chalik, Abdul. "Religion and Local Politics: Exploring the Subcultures and the Political Participation of East Java Nu Elites in the Post-New Order Era." Journal of Indonesian Islam 4, no. 1 (June 1, 2010): 109-50. https://doi.org/10.15642/JIIS.2010.4.1.109-150.

Clark, W.H. The Psychology of Religion: An Introduction to Religious Experience and Behavior. New York: Literary Licensing, 2012. https://books.google.co.id/books?id=kyeIMQEACAAJ.

Dewi, Andini Nurrahmah, and Agus Machfud Fauzi. Peran Tokoh Agama Dalam Meningkatkan Religiusitas Warga Desa Giri, Kabupaten Gresik. Di Masa Pandemi Covid-19. Tajdid. Vol. 24, 2021.

Faridah, Ika Fatmawati. "Toleransi Antarumat Beragama Masyarakat Perumahan." Jurnal Komunitas 5, no. 2 (2013): 267-79.

Izfanna, Duna, and Nik Ahmad Hisyam. "A Comprehensive Approach in Developing Akhlaq: A Case Study on the Implementation of Character Education at Pondok Pesantren Darunnajah.” Multicultural Education \& Technology Journal 6, no. 2 (June 8, 2012): 77-86. https://doi.org/10.1108/17504971211236254. 
Mahdayeni, Muhammad Roihan Alhaddad, and Ahmad Syukri Saleh. "Manusia Dan Kebudayaan (Manusia Dan Sejarah Kebudayaan, Manusia Dalam Keanekaragaman Budaya Dan Peradaban, Manusia Dan Sumber Penghidupan)." TABDIR: Jurnal Manajemen Pendidikan Islam 7, no. 2 (2019): 154-65. https://doi.org/10.30603/tjmpi.v7i2.1125.

Maulana, Dirga. "The Exclusivism of Religion Teachers: Intolerance and Radicalism in Indonesian Public Schools." Studia Islamika 24, no. 2 (August 31, 2017): 395-401. https://doi.org/10.15408/sdi.v24i2.5707.

Maulidah, Robi'atul. “Toleransi Umat Muslim Terhadap Keberadaan Gereja Pantekosa Di Surabaya." Religio: Jurnal Studi Agama-Agama 4, no. 2 (2014): 195-217.

Melfianora. "Penulisan Karya Tulis Ilmiah Dengan Studi Literatur." Open Science Framework, 2017, 1-3.

Meliza, Deri Wanto, and Lukman Asha. "Persepsi Masyarakat Sukaraja, Rejang Lebong Terhadap Edaran Menteri Agama Nomor: SE. 6. Tahun 2020 Mengenai Tata Cara Beribadah Saat Pandemi." MANHAJ: Jurnal Peneltian Dan Pengabdian Masyarakat 9, no. 1 (2020): 1-17.

Mir, Raza A. "Religion as a Coping Mechanism for Global Labor: Lessons from the South Asian Shia Muslim Diaspora in the US." Edited by Jawad Syed and Edwina Pio. Equality, Diversity and Inclusion: An International Journal 32, no. 3 (January 1, 2013): 32537. https://doi.org/10.1108/EDI-12-2012-0111.

Nisa, Suvia'. "Toleransi Masyarakat Beda Agama (Studi Tentang Interaksi Sosial Umat Beragama Di Krisik Blitar),” 2019.

Quway, Nabila. "Intergrasi Multikultural Dalam Masyarakat Multietnis (Jawa, Cina, Dan Arab Keturunan) Di Kota Semarang." Jurnal IJTIMAIY AH 2, no. 1 (2018): 90-110.

Raihani. "Report on Multicultural Education in Pesantren." Compare: A Journal of Comparative and International Education 42, no. 4 (July 1, 2012): 585-605. https://doi.org/10.1080/03057925.2012.672255.

Ridwan, Benny. "DARI MIMBAR RELIGI, KEARIFAN LOKAL, DAN KERJASAMA (Perilaku Kerukunan Beragama Masyarakat Salatiga Dan Manado),” 2018, 1-23.

Roslan Mohd Nor, Mohd, and Maksum Malim. "Revisiting Islamic Education: The Case of Indonesia." Journal for Multicultural Education 8, no. 4 (November 4, 2014): 261-76. https://doi.org/10.1108/JME-05-2014-0019. 
Rosyid, Moh. "KESELARASAN HIDUP BEDA AGAMA DAN ALIRAN: Interaksi Nahdliyin, Kristiani, Buddhis, Dan Ahmadi Di Kudus.” Fikrah 2, no. 1 (2014): 75-94. Ruhana, Akmal Salim, and Haris Burhani. "Pengetahuan, Sikap Dan Tindakan Umat Beragama Saat Menghadapi Covid-19." Laporan Survei, 2020, 1-49.

Siahaan, Amiruddin, Tien Rafida, and Khairunnisa Batubara. "Influence of Madrasah Head Leadership, Motivation and Madrasah Culture on Teacher Performance in Madrasah Aliyah Model 2 Medan." Budapest International Research and Critics Institute (BIRCIJournal): Humanities and Social Sciences 3 (August 3, 2020): 2174-82. https://doi.org/10.33258/birci.v3i3.1150.

Suparlan, Parsudi. "Masyarakat Majemuk, Masyarakat Multikultural, Dan Minoritas: Memperjuangkan Hak-Hak Minoritas.” Pusat Dokumentasi ELSAM, n.d., 2-4.

Supratno, Haris, and Resdianto Raharjo. "Multicultural and Character Education as the Model of Mental Revolution Movement to Prevent Santri Radicalism," 156-59. Atlantis Press, 2017. https://doi.org/10.2991/soshec-17.2018.31.

Syarqawi, Ahmad. "Masyarakat Multikultural," n.d.

Syatar, Abdul, Muhammad Majdy Amiruddin, and Arif Rahman. "Darurat Moderasi Beragama Di Tengah Pandemi Corona Virus Desease 2019 (Covid-19).” Jurnal Kurioritas: Media Komunikasi Sosial Dan Keagamaan 13, no. 1 (2020): 1-13. https://doi.org/10.35905/kur.v13i1.1376.

Umanailo, M Chairul Basrun. "Max Weber," 2017, 1-5. https://doi.org/10.4324/9780203786093.

Wahid, Abdul, Dyp Sugiharto, Samsudi Samsudi, and Haryono Haryono. "Learning Development Based On Multicultural In Inclusion School.” Nadwa 12, no. 2 (January 7, 2019): 229-42. https://doi.org/10.21580/nw.2018.12.2.2744. 